\title{
Impact of Methoxy Polyethylene Glycol-Epoetin Beta on serum magnesium in patients with end stage renal disease undergoing hemo dialysis
}

\author{
Mohanad Mohsen Hassan (MSc) ${ }^{1}$, Adnan Gadbhan Alwan (MSc) ${ }^{2}$
} and Ali Jasim Hashim Alsaedi (FICMS) ${ }^{3}$

\begin{abstract}
Background: Methoxy polyethylene glycol-Epoetin beta (M.PG.E- $\beta$ ) is a long-acting erythropoietin receptor activator treatment indicated for the treatment of patients with anemia associated with end stage renal disease (E.S.R.D). It is the first approved chemically modified erythropoiesis-stimulating agent (E.S.A). Hypermagnesemia is one of the common complications accompanied with E.S.R.D patients submitted to hemodialysis. It progresses early in the course of the disease and increases its rate with the declination in renal efficacy.

Objective: This study targeted to determine the influence of M.PG.E- $\beta$ therapy on serum $\mathrm{Mg}+2$ levels in patients with E.S.R.D.

Patients and Methods: In this study, seventy patients with E.S.R.D on hemodialysis receiving M.PG.E- $\beta$ and twenty healthy subjects without medical illnesses were included in this case-control cross sectional study.

Results: Patients had significantly higher serum $\mathrm{Mg}+2$ level at the baseline $(\mathrm{p}<0.01)$ compared to the healthy control group because of loss of renal function in these patients. M.PG.E- $\beta$ dose was then given three months after the baseline dose and showed a significant decline in serum $\mathrm{Mg}+2$ levels $(\mathrm{p}<0.05)$ in patients with E.S.R.D during the study.

Conclusion: It can be concluded that relative elevation of serum $\mathrm{Mg}+2$ was linked with E.S.R.D patients and the administration of M.PG.E- $\beta$ usually leads to a significant subside in its levels.
\end{abstract}

Key words: End stage renal disease, M.PG.E- $\beta$, Serum Magnesium

Corresponding Author: muhanaid89@gmail.com

Received: $6^{\text {th }}$ December 2016

Accepted: $24^{\text {th }}$ September 2017

https://doi.org/10.26505/

\footnotetext{
${ }^{1,2}$ Deparentment of Medical Laboratory Technology- College of Health and Medical Technology - Middle Technical University - Baghdad - Iraq. ${ }^{3}$ Department of Medicine- College of Medicine- Baghdad University-Iraq.
} 


\section{Introduction}

Methoxy polyethylene glycol-Epoietin beta (M.PG.E- $\beta$ ) is defined as a long acting erythropietn receptor activator indicated for the treatment of patients with anemia associated with end stage renal disease. It is the first approved chemically modified erythropoiesis-stimulating agent (ESA).

M.PG.E- $\beta$ is manufactured from human erythropoietin by chemically linking the $\mathrm{N}$ terminal amino group or the $\mathrm{C}$-amino group of any lysine existing in the erythropoietin protein with Methoxy polyethylene glycol butanoic acid. The drug stimulates erythropoiesis by interacting with the erythropoietin receptor on progenitor cells in the bone marrow [1].

It has been observed that erythropoietin initially acts by transforming and modifying the cationic kinesis.

Magnesium is known to play a vital role in carbohydrate absorption and its discrepancy has been implicated as a cause , consequence or complications of numerous disorders linked with end stage renal disease like Diabetes mellitus and hypertension. Hypermagnesemia is one of the problems that is allied with E.S.R.D. It progresses initially in the sequence of the disease and elevating its concentration with the declination of renal function [2].

When calcium was chelated in the culture medium and in the cell cytoplasm, it was found that calcium is necessary in permitting the hormone to connect to the target cell. The entrance of calcium into the cell and establishment of gradients between its cytoplasm and nucleus seem to be crucial moments in the triggering of replication kinetic[3].

Many other growth factors and diverse cytokines have the same outcome as erythropoietin on intracellular cations. Through exploiting the effect of gardos channel, many growth factors were demonstrated to behave like ionospheric substances toward calcium ions. Determining a significant $\mathrm{Ca}+2$ dependent effusion of $\mathrm{K}+1$ from the cells was studied [4]. Nevertheless, the consequence of erythropoietin on $\mathrm{Ca}$ has been deliberated in depth to our knowledge, few documents are existing in the literature on the association between erythropoietin hormone and other intracellular cations like serum $\mathrm{Mg}+2$ even if it is known that the modification of the concentration of cations is one of the events triggering RNA synthesis [5].

However, it is not known whether this correlation rely on the actual influence of $\mathrm{Mg}+2$ on the construction or on the activity of erythropoietin or rather is linked to nephropathy from cisplatin which is wellknown to be $\mathrm{Mg}+2$ dependent. The influence of erythropoietin on magnesium behavior in E.S.R.D patients are even less well understood, thus some studies interpreted experimental evidence on increasing entrance of ions to inside cells in the early phase of erythropoiesis[6].

The regulation and elimination of magnesium in patients with renal disease is somewhat understudied. Despite this incomplete understanding, we know that 
Impact of Methoxy Polyethylene Glycol-Epoetin Beta on serum magnesium in patients with end stage renal disease undergoing hemo dialysis Mohanad Mohsen Hassan

serum magnesium levels increase when the glomerular filtration rate (GFR) falls below 20-30 $\mathrm{mL} / \mathrm{min}$, yet we do not know what happens to serum magnesium concentration in patients with more modest falls in GFR [e.g. ESRD; GFR $<15$ $\mathrm{mL} / \mathrm{min}$ ] or what proportion of these patients are likely to be hypermagnesaemic[7].

\section{Patients and Methods}

This case-control was carried out on patients who attended Iraqi center of kidney dialysis , Baghdad Teaching Hospital for the period from November 2016 to February 2017(three months). Patients with E.S.R.D, who were receiving M.P.G.E- $\beta$, were selected in our study. All patients (47 male\&23 female) whose ages ranged from 28 to 76 years were diagnosed as having E.S.R.D based on previous medical reports and clinical examination by consultant nephrologists.

The results of those patients were compared with (20) healthy age-matched ( 28-76) years individuals (10 males and 10 females) as a control group. The control group subjects were selected as healthy individuals without a history of kidney disease or previous kidney stones and not suffering from diabetes or hypertension. Venous blood samples $(5 \mathrm{ml})$ were taken from each patient in the morning at (6:0010:00 a.m) just prior to the start of the dialysis session after an overnight fasting. Blood samples of the patients were obtained from needle puncture site of dialyzer to ensure that a pre hemodialysis sample has been obtained. Blood samples were centrifuged for 10 minutes at 3000 RPM to obtain serum which was stored at $(-40 \mathrm{oC})$ until time of assay. This sample is considered as a baseline sample.

Venous blood samples were also taken from the control group by means of disposable syringes and centrifuged to obtain serum. After three months of this baseline sample, the process of blood collection from patients was repeated to compare and follow-up the changes of the test results before and after M.P.G.E- $\beta$ treatment.

\section{Statistical Analysis}

The research was performed using the SPSS (version 20) program (SPSS Inc., Chicago, Illinois, USA). In all judgements, a ( $p$ value $<0.05$ ) was regarded statistically significant. Paired sample $t$ test and Kolmogorov-Smirnov test were achieved to investigate the observance of continuous variables to the normal and abnormal distribution. The chi-square test was used for comparisons of discrete variables between each study group. Discrete variables presented using their number and percentage. 
Impact of Methoxy Polyethylene Glycol-Epoetin Beta on serum magnesium in patients with end stage renal disease undergoing hemo dialysis

Mohanad Mohsen Hassan

\section{Results}

Table (1): Statistical data of age, Hb, Hct, serum urea, serum creatinine and gender of studied groups at baseline (patients and control).

\begin{tabular}{|c|c|c|c|c|c|c|c|}
\hline \multicolumn{8}{|c|}{ Paired sample t test } \\
\hline & \multicolumn{2}{|c|}{$\begin{array}{l}\text { Patients } \\
(\mathrm{n}=70)\end{array}$} & \multicolumn{3}{|c|}{ Control $(n=20)$} & \multirow[t]{2}{*}{ P. value } & \multirow[t]{2}{*}{ S.C } \\
\hline & \multicolumn{2}{|c|}{ Mean \pm SD } & \multicolumn{3}{|c|}{ Mean \pm SD } & & \\
\hline Age & \multicolumn{2}{|c|}{$52.4 \pm 11.2$} & \multicolumn{3}{|c|}{$50.6 \pm 16.1$} & 0.42 & $\mathrm{P}>0.05(\mathrm{NS})$ \\
\hline $\mathrm{Hb}(\mathrm{g} \backslash \mathrm{dl})$ & \multicolumn{2}{|c|}{$8.04 \pm t .34$} & \multicolumn{3}{|c|}{$13.8 \pm 1.13$} & 0.015 & $\mathrm{P}<0.05(\mathrm{~S})$ \\
\hline Hct $(\%)$ & \multicolumn{2}{|c|}{$24.7 \pm 4.04$} & \multicolumn{3}{|c|}{$41.7 \pm 3.13$} & 0.022 & $\mathrm{P}<0.05(\mathrm{~S})$ \\
\hline S.urea (mgldl) & \multicolumn{2}{|c|}{$158.1 \pm 45.1$} & \multicolumn{3}{|c|}{$27 \pm 8.1$} & 0.001 & $\mathrm{P}<0.01(\mathrm{HS})$ \\
\hline $\begin{array}{c}\text { S.creatinine } \\
(\mathrm{mg} \backslash \mathrm{dl})\end{array}$ & \multicolumn{2}{|c|}{$8.5 \pm 2.82$} & \multicolumn{3}{|c|}{$1.2 \pm 0.5$} & 0.001 & 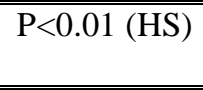 \\
\hline \multicolumn{8}{|c|}{ Chi-Square test } \\
\hline & & $\%$ & $\begin{array}{c}\text { Patients } \\
(\mathrm{n}=70)\end{array}$ & $\%$ & $\begin{array}{l}\text { Control } \\
(n=20)\end{array}$ & P. value & S.C \\
\hline \multirow[t]{2}{*}{ Gender } & \multicolumn{2}{|c|}{ Male } & 47 & 50 & 10 & \multirow[t]{2}{*}{$0.348^{\mathrm{a}}$} & \multirow[t]{2}{*}{$\mathrm{P}>0.05(\mathrm{NS})$} \\
\hline & nale & 33 & 23 & 50 & 10 & & \\
\hline
\end{tabular}

Statistical data of the study groups are expressed in table (1). The subjects enrolled in the present study were matched. However, there was a significant declination $(\mathrm{p}<0.05)$ in the hemoglobin and hematocrit, while highly significant elevation $(\mathrm{P}<0.01)$ in the serum urea and creatinine in the ESRD patients group when compared with the healthy control group.

Table (2): Comparison of mean s. magnesium concentration $(\mathrm{mg} / \mathrm{dl})$ between baseline (patients) and control.

\begin{tabular}{||c||c||c||c||}
\hline Groups & Mean \pm SD & P value & C.S \\
\hline \hline Controls $(\mathrm{n}=20)$ & $2.0 \pm 0.18$ & 0.0316 & $\mathrm{P}<0.05(\mathrm{~S})$ \\
& & & \\
\hline Baseline $(\mathrm{n}=70)$ & $4.50 \pm 1.14$ & & \\
\hline & & & \\
\hline \multicolumn{2}{|l|}{ Kolmogorov-Smirnov Test } \\
\hline
\end{tabular}


Impact of Methoxy Polyethylene Glycol-Epoetin Beta on serum magnesium in patients with end stage renal disease undergoing hemo dialysis

Mohanad Mohsen Hassan

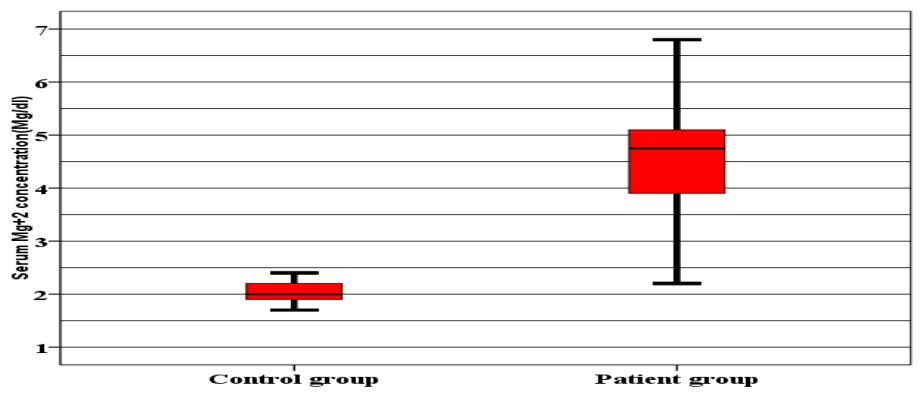

Figure (1) : Comparison of mean s. magnesium concentration $(\mathrm{mg} / \mathrm{dl})$ between baseline (patients) and control

Table (2) \& figure (1) indicated that there was a significant difference in mean serum magnesium concentration between the patients group $(4.50 \pm 1.14)$ and control (2.0 \pm 0.18$)$.

Table (3): Comparison of mean s. magnesium concentration $(\mathrm{mg} / \mathrm{dl})$ between baseline time and after 3 months of M.P.G.E- $\beta$ treatment.

\begin{tabular}{|c|c|c|c|}
\hline Groups & $\begin{array}{l}\text { Meant } \\
\text { SD }\end{array}$ & $\mathrm{P}$ value & S.C \\
\hline Baseline $(n=70)$ & $4.5 \pm 1.14$ & \multirow[t]{2}{*}{0.01} & \multirow[t]{2}{*}{$\begin{array}{l}\mathrm{P}<0.05 \\
(\mathrm{~S})\end{array}$} \\
\hline After 3 months $(n=70)$ & $3.1 \pm 0.91$ & & \\
\hline \multicolumn{4}{|c|}{ Paired Sample Test ( two tail ) } \\
\hline
\end{tabular}

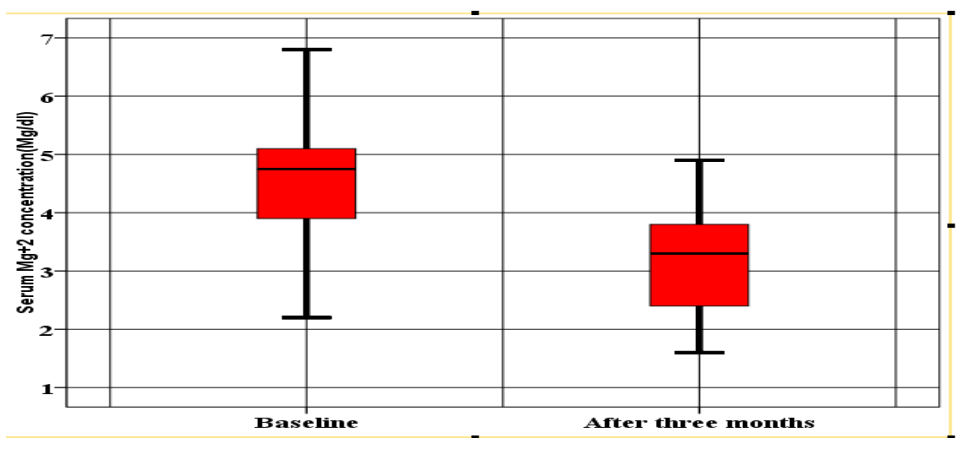

Figure (2): Comparison of mean s. magnesium concentration $(\mathrm{mg} / \mathrm{dl})$ between baseline time and after 3 months of M.P.G.E- $\beta$ treatment.

Table (3) \& figure (2) indicated that there was a significant difference in mean serum magnesium concentration between the baseline time (4.5 \pm 1.14$)$ and after 3 month of treatment with M.P.G.E- $\beta$ (3.1 \pm 0.91$)$. 


\section{Discussion}

Serum magnesium is one of the major intracellular cations in the body. For normal neuromuscular activity, humans need normal concentration of extracellular magnesium. Intracellular magnesium is an important cofactor for various enzymes, transporters and nucleic acids that are necessary for normal cellular function , replication , and energy metabolism[8,9].

Selection of age and gender matched individuals was necessary in our study to obtain precise results regards the effect of M.PG.E- $\beta$ treatment on magnesium level , therefore no significance difference was found between patients and control in regard age and gender. Our comparative study regarding the effect of M.PG.E- $\beta$ on serum $\mathrm{Mg}+2$ level was carried on E.S.R.D patients on hemodialysis at baseline and after three months of treatment and compared with healthy controls.

In healthy people, intestinal magnesium absorption and renal excretion are regulated so as to maintain magnesium balance [10,11].

The fractional absorption of magnesium (which occurs mainly in the small intestine) adapts to dietary intake. Under normal conditions, $\sim 30-50 \%$ of ingested magnesium is absorbed. However, the fractional absorption of magnesium rises to $80 \%$ if intake is low and falls to $25 \%$ when magnesium intake is high[12].

The current study showed that in patients with E.S.R.D , serum $\mathrm{Mg}+2$ level was significantly higher at baseline period when compared with normal healthy subjects. The results showed that the patient group had significantly higher serum levels of $\mathrm{Mg}+2 \quad(\mathrm{p}<0.05)$ when compared with the control group. Such finding was also observed by other studies $[2,13]$.

The variation between control and baseline may be attributed to the renal excretion control and to the distribution of electrolytes during hemodialysis or may be due to M.PG.E- $\beta$ treatment.

Also there was a significant decrease in serum $\mathrm{Mg}+2$ level $(\mathrm{p}<0.05)$ in patients from the beginning of administration of recombinant erythropoietin (M.P.G.E $\beta$ ) at baseline (start point of follow up) and after 3 months. These data were illustrated in table (3) and figure (2). M.P.G.E $\beta$ which is a recombinant erythropoietin as we mentioned before has triggered a reduction of $\mathrm{Mg}+2$ level in E.S.R.D patients after three months a finding that agrees with $[14,15,16]$, but is inconsistent with[17].

The finding in this study revealed that erythropoietin may cause essential modification and declination in the capacity of $\mathrm{Mg}+2$ in the E.S.R.D patients and this in agreement with[ 18]. Among issues that elucidate why erythropoietin effect on $\mathrm{Mg}+2$, is the diverse in $\mathrm{Mg}+2$ and calcium content that originated from the uremic subjects[19,20].

Beside the influence of M.P.G.E $\beta$ treatment on $\mathrm{Mg}+2$, by contrast, hemodialysis treatment may be cause 
Impact of Methoxy Polyethylene Glycol-Epoetin Beta on serum magnesium in patients with end stage renal disease undergoing hemo dialysis

reduction in its level. Serum magnesium concentration in patients on hemodialysis are often slightly elevated above the normal range and have been shown to be dependent on residual renal function[21,22].

On dialytic elimination (reviewed by Hutchison and Wilkie) [23], they were described that in mild hypermagnesaemia when using a magnesium dialysate concentration of $0.75 \mathrm{mmol} / \mathrm{L}$ in hemodialytic patients, happened decrease in magnesium concentration, Several studies have investigated ionized serum magnesium in dialysis patients was elevated in comparison with healthy controls. A lower ionized fraction could be due to a higher fraction of complexed magnesium (phosphates, citrate, sulphates) in dialysis patients than in healthy individuals[24].

\section{Conclusions}

Significant serum $\mathrm{Mg}+2$ elevation is common in E.S.R.D patients who are on hemodialysis.The administration of recombinant erythropoietin (M.PG.E- $\beta$ ) typically leads to a significant subsiding in serum $\mathrm{Mg}+2$ levels in these patients.

\section{Recommendations}

1-A huge and multi-center study is essential to support and clarify these outcomes.

2-Addition of other biochemical parameters to future studies is necessary to expand the information on the impact of such treatment.

\section{References}

[1] Macdougall, Iain C, Eckardt , KaiUwe, "Novel strategies for stimulating erythropoiesis and potential new treatments for anaemia". The Lancet. 2006; 368 (9539): 947-953.

[2] Shashidhar K. N , Kunder M , Shenoy K. A , Hemalatha A, Kutty , A.V.M. \& Shetty, H. V. Hypermagnesemia in diabetic end stage renal disease (ESRD) patients. Indian Journal of Clinical Biochemistry, 2007; 22(2), 164-164.

[3] Lawrence, W. D., Davis, P. J., \& Blas, S. D. Action of erythropoietin in vitro on rabbit reticulocyte membrane $\mathrm{Ca} 2+-$ ATPase activity. Journal of Clinical Investigation, 1987; 80(2), 586.

[4] Buemi M ,Allegra A , Marino M, D Anna R, palella S, Corica F, Frisina N : Effect of some growth factors on the $\mathrm{Ca}++$ flow in whole erythrocytes from hypertensive and pregnant subjects with gestational hypertension. High Blood press : 1995; 4:204-208.

[5] Allegra, A., Corica, F., Ientile, R., Naso, A., Corsonello, A., Montalto, G., ... \& Buemi, M. Effect of intravenous recombinant erythropoietin administration on plasma and erythrocyte magnesium concentrations in patients on hemodialysis. Nephron, 1996; 74(2), 499-500.

[6] Millart, H., Durlach,V, \& Durlach, J. Red blood cell magnesium concentrations: Analytical problems and significance. Magnesium research, 1995; 8(1), 65-76.

[7]Saha,H.H.;Harmoinen,A.P.;PasternackC

$\mathrm{K}$,Amos I.Measurement of serum ionized 
Impact of Methoxy Polyethylene Glycol-Epoetin Beta on serum magnesium in patients with end stage renal disease undergoing hemo dialysis Mohanad Mohsen Hassan

magnesium in CAPD patients. Peritoneal dialysis international, 1997, 17.4: 347-352. [8]BishnuP.Devkota,.(2014).Magnesium.htt p://emedicine.medscape.com/article/208814 0-overview.

[9]Toprak,Omer,etal.Magnesiumreplaceme nt improves the metabolic profile in obese and pre-diabetic patients with mild-tomoderate chronic kidney disease: a 3month, randomised, double-blind, placebocontrolled study. Kidney and Blood Pressure Research, 2017, 42.1: 33-42.

[10] DE BAAIJ, Jeroen HF; HOENDEROP, Joost GJ; BINDELS, René JM. Regulation of magnesium balance: lessons learned from human genetic disease. Clinical kidney journal, 2012, 5.Suppl_1: i15-i24.

[11]Navarro-Gonzalez,Juan.F.;MoraFernandez,Carmen;Garcia-Perez,Javier.

Reviews: clinical implications of disordered magnesium homeostasis in chronic renal failure and dialysis. In: Seminars in dialysis. Blackwell Publishing Ltd, 2009. p. 37-44.

[12]Sera,K., et alElemental concentration in the hair taken from healthy people for the past 20 years - 1 . Long-term changes over 20 years. International Journal of PIXE, 2016, 26.01n02: 15-28.

[13] Spiegel, D. M. Magnesium in chronic kidney disease: Unanswered questions. Blood purification, 2011; 31(1-3), 172-176. [14] Kisters, K., Spieker, C., Tepel, M., Wenserski, F., \& Zidek, W. (). Plasma, cytosolic and membrane magnesium content in renal insufficiency. Magnesium research, 1995; 8(2), 169-174.

[15]Tsompos, C., Panoulis, C., Toutouzas, K., Zografos, G., \& Papalois, A. The effect of erythropoietin on magnesium during ischemia reperfusion injury in rats. Romanian Journal of Neurology, 2014; 13(1).

[16]Mountokalakis, T. D. Magnesium metabolism in chronic renal failure. Magnesium research, 1990; 3(2), 121-127.

[17]Nakamura, M., Suzuki, H., Yamakawa, H., \& Saruta, T. Role of platelet cytosolic calcium in regulation of blood pressure in patients on chronic hemodialysis. Nephron, 1992; 61(4), 435-441.

[18]Chandorkar,Gurudatt A., et al. Pharmacokinetics, Pharmacodynamics, and Safety of Single and Multiple Oral Doses of Vadadustat in Healthy Japanese and Caucasian Subjects: American Society of Nephrology's Kidney Week. Chicago, American Society of Nephrology, 2016.

[19] Barton, I. K., Mansell, M. A., \& Grimes, A. J. Red-cell calcium in patients with renal failure. Nephron, 1987; 47(2), 123-124.

[20]Van Hasselt,Peter M.; CLAYTON, Peter T.; HOUWEN, Roderick HJ. Disorders in the transport of copper, iron, magnesium,

manganese, selenium and zinc. In: Inborn Metabolic Diseases. Springer Berlin Heidelberg, 2016. p. 531-548.

[21]Saha, H. H.; Harmoinen, A. P.; PASTERNACK, Amos I. Measurement of serum ionized magnesium in CAPD 
Impact of Methoxy Polyethylene Glycol-Epoetin Beta on serum magnesium in patients with end stage renal disease undergoing hemo dialysis

patients. Peritoneal dialysis international, 1997, 17.4: 347-352.

[22] Hutchison, Alastair J.; WILKIE, Martin. Use of magnesium as a drug in chronic kidney disease. Clinical kidney journal, 2012, 5.Suppl_1: i62-i70.

[23]Jahnen-Dechent,Wilhelm; KETTELER, Markus. Magnesium basics. Clinical kidney journal, 2012, 5.Suppl_1: i3-i14.
[24] Huijgen, H. J., Van Ingen, H. E., Kok, W. T., \& Sanders, G. T. Magnesium fractions in serum of healthy individuals and CAPD patients, measured by an ionselective electrode and ultrafiltration. Clinical biochemistry, 1996; 29(3), 261266. 